\section{SAFE CONTAINER UNLOADING PROCEDURES: AN OBLIGATION OR NOT IMPORTANT?}

S Verpaele*. Becoh Vzw, Zwijnaarde, Belgium

\subsection{6/oemed-2018-ICOHabstracts.675}

Introduction Several studies have shown that there may be concerns about exposure to dangerous substances for workers unloading sea freight containers, although safe procedures for unloading containers are usually in place to protect workers from being exposed to chemical agents. Since preliminary research has shown that less than $1 \%$ of unloaded containers are deliberately fumigated with known chemicals, it was necessary to find the root cause.

Methods Many production sites for sea freight containers are located in Asia. The first task in this study was the identification of production factories and their locations. The second task was to identify the full production cycle of the goods that are manufactured and shipped via freight containers. The third task was to gather exposure data during the production cycle and identify off-gassing post production, when loading containers for travel to Europe.

Results All tasks took about six years to complete, and identified a way to predict container air concentration on the unloading site (downstream) based on information at the production site (upstream). This algorithm is based upon site concentration measurements, lab experiments of the raw materials and unloading concentration measurements. These parameters can be applied for the full production cycle and are independent of variations in terms of production site outputs.

Discussion Safe container unloading procedures are now based on an upstream limit value, meaning that if the concentration at a production site is higher than the established limit value, the goods cannot be shipped by container, or the container is required to be ventilated at the unloading site. This case study series is a good example of how occupational hygiene principles can be used in root cause analysis and problem solving, in terms of exposures to chemical agents.

\section{OCCUPATIONAL HEALTH: FROM ENFORCEMENT TO PREVENTION AND REHABILITATION}

\begin{abstract}
${ }^{1} \mathrm{HO}$ Siong Hin, ${ }^{2} \mathrm{~A}$ Darus, ${ }^{3} \mathrm{~A}$ Hiddinga-Schipper, ${ }^{4} \mathrm{M}$ O'Halloran, 5,6 Park Doo Yong, ${ }^{7}$ Yushi Fujita. ${ }^{1}$ International Association of Labour Inspection, and Commission for Workplace Safety and Health, Ministry of Manpower, Singapore; ${ }^{2}$ Social Security Organization of Malaysia (SOCSO); ${ }^{3}$ Arbo Unie, Netherlands; ${ }^{4}$ Health and Safety Authority, Ireland; ${ }^{5}$ Department of Mechanical Systems Engineering, Hansung University, Seoul, Republic of Korea; ${ }^{6}$ Korea Occupational Safety and Health Agency; ${ }^{7}$ The International Ergonomics Association
\end{abstract}

10.1136/oemed-2018-ICOHabstracts.676

Aim of special session To consider various aspects of occupational health enforcement, prevention and rehabilitation in a range of settings.

\section{0a REHABILITATION PARADIGM: RETURN TO WORK FROM DISABILITY}

A Darus. Social Security Organization of Malaysia (SOCSO)

10.1136/oemed-2018-ICOHabstracts.677
Evidence based, both scientifically and practical experience have indicated that maintaining a disabled worker's attachment to a pre-disability employment prior to entering some form of social security assistance, has, contingent upon jurisdictional circumstances, delivered some impressive socio-economic outcomes.

SOCSO receives over 75,000 new claims a year with a majority of these cases coming from its employment injury scheme and the rest coming from its invalidity pension scheme; despite various prevention activities being implemented. With such findings, SOCSO reengineered its complete operations to ensure that every claim is managed to ensure that the workers or their family members are protected. Operational reengineering had also considered early intervention to reduce disability or impairment when an accident or diseases occur.

It has been slightly over 10 years since the establishment of the SOCSO Return to Work Program which has been the catalyst for the establishment rehabilitation and social reintegration activities for injured and disabled workers in the country. This has culminated in over 14 thousand cases who had went through the program and returned to gainful employment.

This session will provide an overview of the challenges that Malaysia faced in the effective re-integration of injured and disabled workers, the rationale for adopting international best practice professional standards in Return to Work and Disability Management, together with the implementation process adopted and will highlight practical considerations - both challenges and opportunities in the roll-out across our country.

\section{0b EMERGING TRENDS IN OCCUPATIONAL HYGIENE}

\section{A Hiddinga-Schipper. Arbo Unie, The Netherlands}

\subsection{6/oemed-2018-ICOHabstracts.678}

Although the challenges of the occupational hygienist are still the same as at the beginning of our profession, the role of Industrial Hygienists is changing. To understand the changes that are happening all around us we have to see the bigger picture. Key trends and changes in the world of work can be found in relation to economic, demographic, technological and environmental changes.

The effect of economic growth still influences decent employment and social protection (moving heavy industry to developing countries with less (strict) OSH regulations). The demographic changes influences the different areas of the world differently. Looking at our profession we see these changes influence our own future.

Towards technological and environmental changes, we see it will bring new jobs but it will also destruct jobs as a result of the automatization, robotization. The trend in our work as occupational hygienist has, shifted over years from reducing the number of exposed workers in heavy industries (welding, foundries) to the more psychosocial risks and optimisation of comfort/wellbeing (operator in control room, higher workloads, outsourcing and temporary contracts).

The developments in measurement-techniques (exposure to dust/vapours) have not changed enormously since the personal sampling pump has been developed. But the influence of computer technology and direct readable/ continuous sensing equipment (sensor, monitors, use of apps on mobile phones) 
will increase the amount of data largely and the way the occupational hygienist will use this for exposure assessment.

But overseeing all of these changes, in the end, it will still be the question whether we as occupational hygienist are able to tell our stories in a way that companies and governments see the business relevance of our case. To get our business back on the political agenda we have to learn to communicate about risks in the right way and address our skill gaps.

\section{C IRELAND'S REGULATORY FRAMEWORK ON OCCUPATIONAL SAFETY AND HEALTH: PREVENTION AND ENFORCEMENT, POLICY AND PRACTICE}

M O'Halloran. Health and Safety Authority, Ireland

\subsection{6/oemed-2018-ICOHabstracts.679}

An overview of the evolution of workplace safety and Health including wellbeing and mental health in workplaces in Ireland since 1989 with a particular focus on the period since 2005 . I will outline the operational policy and practice of the Health and Safety Authority in terms of prevention and enforcement up to and including prosecution.

I will explore the legislative base, the information and advice platforms, our collaborative and partnership working, provision of tools to duty holders and proportionate risk based enforcement. The objective has been to raise awareness across the population and duty holders, to change behaviours, and to hold the non-compliant to account.

The Authority has developed a number of three year rolling strategies over the periods which have guided the development of annual programmes of work. The authority has been instrumental in developing some internationally recognised and acclaimed models and tools for implementing a preventive approach.

The authority has adopted the use of social media to promote the messages and has also become active in the national education systems to promote and train students so they are ready and competent with an appreciation of the duties of care owed to them when they enter the workforce.

We have also worked in a very collaborative and partnership manner engaging other state organizations as well as private sector representative groups including $\mathrm{OSH}$ community voluntary groups in promoting a common message and developing and implementing agreed action plans. Other aspects to be covered include research to underpin objective interventions, which are evidence based and evaluating their impacts.

I will review performance achieved over the period also outline the difficulties and challenges still facing the organisation which will require further work to achieve the sustained downward trend that is sought in occupational safety, health, wellbeing and mental health.

\section{0d TRENDS IN MUSCULOSKELETAL DISORDERS}

Yushi Fujita. The International Ergonomics Association

10.1136/oemed-2018-ICOHabstracts.680

\section{0e THE STRUGGLE OF SOCIAL DIMENSION ON OCCUPATIONAL HEALTH WITH ENVIRONMENTAL AND ECONOMIC CHANGES}

1,2Park Doo Yong. 'Department of Mechanical Systems Engineering, Hansung University, Seoul, Republic of Korea; ${ }^{2}$ Korea Occupational Safety and Health Agency

\subsection{6/oemed-2018-ICOHabstracts.681}

Environmental and economic changes that have a great impact on occupational health will be reviewed both macroscopically and microscopically.

A macroscopic principle for a desirable national and societal system of occupational health and safety (OSH) will be introduced to define the social dimension and responsibility on OHS. In this perspective, it will be discussed:

1. the importance of social dimension of OHS;

2. the role of governmental and public sectors in the viewpoint of social dimension to change industry and commerce in response to calls for social and responsible business and OHS; and

3. countervailing forces for hope in the future.

\section{$1770 f$ THE CASE OF RISING OCCUPATIONAL HEALTH STANDARDS IN SINGAPORE}

HO Siong Hin. International Association of Labour Inspection, and Commission for Workplace Safety and Health, Ministry of Manpower, Singapore

10.1136/oemed-2018-ICOHabstracts.682

\section{Mining Occupational Safety and Health}

\section{MERCURY EXPOSURE AND RELATED HEALTH PROBLEMS AMONG ARTISANAL AND SMALL SCALE GOLD MINING COMMUNITY IN CHUNYA DISTRICT TANZANIA}

${ }^{1}$ Simon Mamuya, ${ }^{2}$ Stanford Mwakitwange. 'Muhimbili University of Health and Allied Sciences, Dar es Salaam, United Republic of Tanzania; '2District medical Officer, Chunya, Tanzania

\subsection{6/oemed-2018-ICOHabstracts.683}

Background Human exposure to elemental mercury occurs mainly through inhalation of vapours, contact and ingestion through consumption of contaminated sea food.

Objective To assess the magnitude of health problems related to mercury exposure among artisanal and small scale gold mining community in Chunya District.

Methodology Analytical cross section study was conducted in gold mine community in Chunya District. A multistage random sampling method was used to recruit study participants from Saza and Makongorosi mining area recruited as exposed and individuals from two wards surrounding the mining area as unexposed group. Data was collected by a pre-tested interview schedule administered face to face to the interviewee 